\title{
Why not order direct-to-consumer genetic testing for your children?
}

\section{ELINE M. BUNNIK ${ }^{1}$}

Predictive genetic testing in childhood is generally considered morally justified only if there are clear medical benefits to be obtained from testing that cannot be obtained otherwise. ${ }^{2}$ In clinical genetics, physicians and genetic counsellors have traditionally acted as gatekeepers against unwarranted genetic testing of children, protecting them against harm and respecting their right not to know genetic information. Today, individuals may access direct-to-consumer online genetic profiling services that lack such systems of control. Companies sometimes encourage their customers to order genetic testing not only for themselves, but also for their children. ${ }^{3}$ By purchasing genetic testing for their children, parents are depriving those children of future opportunities for autonomous medical decision-making. In a recent policy-oriented report on medical profiling and online medicine, the authoritative UK-based Nuffield Council on Bioethics slightly overlooks and misrepresents the central ethical issues in childhood testing in four ways.

First, in its section on direct-to-consumer genetic profiling, the Nuffield report recommends that children ought not to be tested for conditions that do not meet the National Screening Committee (NSC) list of criteria. ${ }^{4}$ This list, an adaptation of the original Wilson and Jungner criteria from the late $1960 \mathrm{~s},{ }^{5}$ has been composed for the purposes of the (ethical) evaluation of national screening programmes. Many of these criteria, such as "the condition must be an important public health problem", are intended to be applied to population-based (or large-scale) public health programmes. In the rather different healthcare situation in which individual consumers are to undergo genetic testing on their own or their parents' initiative, the suitability of these criteria is unclear. For example, NSC criteria such as "the programme should be acceptable to health professionals and the public" 6 and "the programme should represent value for money"7 are not directly relevant to the evaluation of consumerdriven individual genetic profiling. The Nuffield report applies a set of existing criteria to novel practices, but it does not argue whether and how such translation is justified.

Second, the Nuffield report formulates another recommendation with regard to the testing of children, namely that valid parental consent is required. When sending their child's DNA sample to a laboratory, customers should "click on a statement confirming that they [...] have parental responsibility in the case of children." ${ }^{8}$ It is questionable whether the 'clicking on a statement' may constitute valid parental consent. One might argue that the validity of consent depends largely on its being informed. While the concept of informed consent has been widely discussed, its ethical significance has rarely been challenged. In present-day clinical genetics, informed consent is a central part of the counselling trajectory and understood to be a 
careful, face-to-face communicative process to ensure informed, autonomous decision-making on the part of the counsellee. ${ }^{9}$ It is a matter of debate whether such very stringent consent requirements should also apply to the commercial context of direct-to-consumer genetic profiling, but in any case something like informed consent will be ethically required. This process should not be reduced to the clicking on a statement.

Third, the absence or presence of parental consent is irrelevant to a more important ethical issue: may parents rightfully purchase genetic profiling at all for their children? Precisely this question should be the focus of an ethical evaluation of online genetic profiling services for children or minors. One of the fundamental principles of medical ethics is respect for the autonomy of persons and the consequent right not to know certain information. For this reason, children are commonly not tested for lateonset diseases in clinical genetics. ${ }^{10}$ Only a positive balance of benefits and harms may justify predictive genetic testing in children, such as when early interventions may bring medical benefit to the child. Most online genetic profiling services, on the other hand, convey personal risk information of limited clinical validity for late-onset complex diseases. As yet, such information has not proven to yield any medical benefit. ${ }^{11}$ In the absence of medical benefit, convincing reasons to override the child's right not to know are lacking. ${ }^{12}$ Therefore, genetic profiling should currently not be offered in childhood, and it follows that parents should refrain from purchasing online genetic profiling for their children. The Nuffield Council may or may not support these conclusions, but in any case it is clear that its recommendation to have parents 'click on a statement' is unlikely to help raise awareness of the real ethical issues surrounding genetic testing in children and minors.

Finally, the Nuffield report argues on the basis of the principle of harm reduction and thus considers ethical issues surrounding childhood testing primarily in terms of harm. It acknowledges that it may be harmful or stigmatising to children to know their genetic risk, "given that" the children and parents involved "cannot un-know" the information and that the child "did not decide himself or herself to take the DNA profiling test." 13 The child's right not to know is thus subsumed under the heading of harm. But not only should children be protected against harm - and so against harmful information; they should also be protected against undue infringements upon their right not to know. The latter is a separate and important ethical issue that ought to be presented such.

In conclusion, predictive genetic testing of children is warranted almost exclusively in cases of (early-onset) diseases for which there are therapeutic or preventive options that must commence in childhood in order to be effective. In other cases, genetic testing ought not to be conducted until individuals may decide for themselves whether or not to undergo testing and are able to provide informed consent. The Nuffield report fails to address the problem of autonomy and the basic right not to know genetic information about oneself. Policy recommendations need to take the guiding 
ethical principle into account that, where possible, genetic testing ought to be deferred until adulthood.

\footnotetext{
${ }^{1}$ Erasmus University Medical Centre in Rotterdam. e.bunnik@erasmusmc.nl

${ }^{2}$ European Society of Human Genetics. Genetic testing in asymptomatic minors: Recommendations of the European Society of Human Genetics. Eur J Hum Genet 2009; 17(6): 720-721.

${ }^{3}$ H.C. Howard, D. Avard, P. Borry. Are the kids really all right? Eur J Hum Genet 1 June 2011 (Epub ahead of print).

${ }^{4}$ Nuffield Council on Bioethics. 2010. Medical Profiling and Online Medicine: The ethics of 'personalised healthcare' in a consumer age. London. Nuffield Council on Bioethics.

${ }^{5}$ J.M.G. Wilson and G. Jungner. 1968. Principles and practice of screening for disease. In Public Health Papers no. 34. Geneva. World Health Organisation (WHO).

${ }^{6}$ Nuffield Council on Bioethics, op. cit. note 3, p. 143.

${ }^{7}$ Ibid, p. 144.

${ }^{8}$ Ibid, p. 161. Emphasis added.

${ }^{9}$ H. Kääriäinen et al. (EurGentest Unit 3). 2008. Recommendations for genetic counselling related to genetic testing. Leuven. EuroGentest Network of Excellence.

${ }^{10}$ R.E. Duncan, J. Savulescu, L. Gillam, R. Williamson and M.B. Delatycki. An international survey of predictive genetic testing in children for adult onset conditions. Genet Med 2005; 7:390-396.

${ }^{11}$ A.C.J.W. Janssens and C.M. van Duijn. An epidemiological perspective on the future of direct-toconsumer personal genome testing. Investig Genet 2010; 1:10.

${ }^{12}$ P. Borry, L. Stultiens, H. Nys, J.J. Cassiman and K. Dierickx. Presymptomatic and predictive genetic testing in minors: A systematic review of guidelines and position papers. Clin Genet 2006; 70: 374381.

${ }^{13}$ Nuffield Council on Bioethics, op. cit. note 3, p. 161.
} 